\title{
Impulsiveness in Alcohol Addiction and Pathological Gambling
}

\author{
Davor Bodor ${ }^{1}$, Andrea Tomić ${ }^{2}$, Neven Ricijaš̌ ${ }^{3}$, Zoran Zoričić ${ }^{4}$, \\ Igor Filipčić \\ 1 Psychiatric hospital "Sveti Ivan", Zagreb, Croatia; ${ }^{2}$ University Psychiatric Hospital \\ Vrapče, Zagreb, Croatia: ${ }^{3}$ University of Zagreb, Faculty of Education and Rehabilitation \\ Sciences, Croatia; ${ }^{4}$ Department of psychiatry, University Hospital Center Sestre milosrd- \\ nice, Zagreb, Croatia
}

\begin{abstract}
Summary: Numerous conducted studies, as well as the daily clinical experience, proves the importance of the role that impulsiveness plays in the clinical course and the treatment response in both psychoactive substance addictions, such as alcohol use disorder and behavioural addictions, such as gambling addiction. In the daily practice, impulsiveness as a personality trait is observed either in the context of a determining, i.e. causing factor in the personality development or as a result of a developed addiction. Certain types of impulsiveness are more often present in certain types of addicts and their detection enables us to make a more precise diagnosis and sub-classification as well as a more adequate adaptation of the treatment protocol. According to the studies so far, the occurrence of impulsiveness significantly affects the occurrence of relapse in treated addicts. To a large extent it also determines the range of the treatment response to the applied treatment procedures. The objective of this review was to point out the specific features of the prevalence of certain impulsiveness elements in psychoactive substance addicts, such as alcohol addicts, and of behavioural addicts, such as gambling addicts, and to additionally emphasize their clinical, diagnostic, treatment and prognostic value.
\end{abstract}

Key words: pathological gambling, alcoholism, impulsive behaviour.

Copyright @ 2015 KBCSM, Zagreb

e-mail: alcoholism.kbcsm@gmail.com•www.http//hrcak.srce.hr/acoholism

\section{Introduction}

Impulsiveness is one of the main features of a series of psychiatric entities such as ADHD, gambling addiction, disorders related to psychoactive substance use, impulse

Correspondence to:

Davor Bodor, md, Psychiatric hospital "Sveti Ivan", Jankomir 11, 10090 Zagreb, Croatia,

E-mail: Davor.Bodor@pbsvi.hr control disorders such as pyromania and certain personality disorders such as antisocial and borderline personality disorder.

According to Moeller et al., impulsiveness can be defined as a predisposition towards rapid, unplanned reactions to internal and external stimuli regardless of the negative consequences of these reactions [1]. In accordance with the latest studies, there is a tendency to describe impulsiveness as a mul- 
tidimensional construct within which the behavioural impulsiveness is described as the impossibility of stopping the initiated reaction or action and cognitive impulsiveness as the impossibility to form an adequate judgement on the consequences of somebody's behaviour. These two dimensions of impulsiveness are described as independent and different phenomena. It can be assumed that in the future these constructs will be additionally developed and complemented [2]. Conceptual definitions of impulsiveness often state the following dimensions: lack of perseverance, sensation seeking, i.e. new contents, lack of premeditation before acting, urgency and increased sensitivity to gratification [3].Impulsiveness is also often described as a part of personality traits and so do Patton et al. distinguish between the motoric aspect of impulsiveness related to action without premeditation and cognitive aspect related to urgent decision-making, non-planning, which is described as focusing on the present and having difficulties to maintain attention [4]. Impulsiveness can be quantified in two ways - by self-reports and neuropsychological tests which use specific movements with the aim to evaluate various components of impulsiveness such as the time thinking was initiated, i.e. making slow or fast decisions in situations of high insecurity. Delaying gratification and fast response are two clear ways a person can operationalize impulsiveness $[5,6]$.

A large number of conducted studies showed that addicts had scored generally higher on the impulsiveness scale of selfevaluation scales than persons not diagnosed with an addiction, i.e. not consuming psychoactive substances and that impulsiveness was one of the most important factors for developing and maintaining addiction [7,8]. This was also supported by the fact that the very diagnostic criteria for diagnosing an addiction syndrome also overlapped to a large extent with the elements of the impulsiveness definition. The previous research studies showed that impulsiveness plays an important role in the clinical course, i.e. it represents an important predictive factor for the occurrence of relapse and significantly affects the response to treatment of both addicts on psychoactive substances, such as alcohol addicts, and gambling addicts, as the only recognised behavioural addicts $[9,10]$.

With psychoactive substance addictions, as with behavioural addictions, impulsiveness can be observed as the determining factor or the vital causative factor for the development of an addiction, but also as a consequence of psychoactive substance addictions. As a determinant or one of the causative factors, impulsive personality traits represent a risk factor for beginning to experiment with psychoactive substances, developing addiction and making abstinence more difficult once the addiction is developed and the change of the impulsiveness intensity is in direct correlation to the amount of the psychoactive substance consumption [11]. However, psychoactive substances per se can have an impact on impulsiveness, an acute one, i.e. due to their primary effect, but also as a longterm consequence of psychoactive substance consumption. The acute effect of alcohol, as well of other psychoactive substances, results in a reduction of inhibition, i.e. a change of the decision-making process, thus raising the probability of engaging in all forms of risk behaviour. It is also important to state that the pattern of a continuous psychoactive substance consumption is developed and supported by a direct effect of psychoactive substances on mental decision-making 
processes, i.e., decision-making [12]. Each impulsiveness dimension reflects various aspects of drug use. Impulsiveness related to the impossibility of postponing a reward, i.e., pleasure can affect the suppressed vulnerability of a person who begins to use drugs and who, due to the quick response, continues to consume the psychoactive substance, i.e. it can contribute to maintaining the misuse of drugs among persons already using drugs. Such described impulsiveness encourages the individual's decision on taking or abstaining from drugs, so that the impulsive fast response may be activated by the pattern of automatically taking drugs such as a short, reactive behaviour [5].

\section{Impulsiveness in Alcohol Addicts}

Consumption of alcohol and other psychoactive substances is often described as a need for a momentary gratification, i.e., reward and so does Ainslie describe impulsiveness as a choice between a short-term and momentary gain in the sense of direct pharmacological effects of psychoactive substances, at the expense of a larger, long-term loss that may include inter-social relations, somatic status etc. ${ }^{13}$ When speaking of gratification, i.e., sensitivity to rewards, Dawe et al. emphasise two dimensions of impulsiveness that are related to the misuse of psychoactive substances. These are sensitivity to a reward and reckless impulsiveness [14].

There are more studies in the field of alcoholism which emphasise impulsiveness as one of the most important aspects of developing and maintaining addiction. Impulsiveness as a personality trait is thus part of multidimensional typologies of alcoholism in which Babor et al. describe Type A [15]. alcoholism while Cloninger et al. describe Type B alcoholism [16,17].
The diagnostic criteria for the syndrome of alcohol addiction are also to a certain extent overlapping with elements of the impulsiveness definition. In accordance with this, cognitive impulsiveness could be referring to the diagnosis criteria for continuing drinking alcohol despite obvious evidence of its harmful consequences, which means that an alcohol addict has a damaged mental decision-making process and, in this case, decisions are made without taking into account and considering negative consequences of a particular decision. The diagnostic criteria related to difficulties of self-control if a person tries to stop drinking or control the amount of the consumed alcohol and would refer, however, to behavioural impulsiveness [9]. The described overlapping of clinical features of alcohol addiction with impulsiveness forms additionally emphasizes the significance and importance of impulsiveness in the clinical course of alcohol addiction.

There are many factors referring to the correlation between alcohol addiction and impulsiveness. Impulsiveness, regardless of its type, like some other factors, such as depression, is described as a significant risk factor for the occurrence of relapses in alcohol addicts $[17,18]$. Poling et al. showed that the occurrence of depression as a heterotypic comorbidity in alcohol addicts increased the risk of developing a relapse, while impulsiveness represented a significant response predictor for patients on the treatment protocol. The interrelationship between the intensity of depressive symptoms and impulsiveness were studied by Jakubczyk et al. and they established that there was a significant correlation between the expressivity of depressive symptoms and impulsiveness. However, this correlation existed only in relation to cognitive impulsiveness, i.e., it was more expressive 
in the case of impulsive decision-making in relation to impulsive behaviour [20]. In the study conducted by Joos et al. cognitive impulsiveness was also related to an emotional yearning for alcohol and the correlation was more emphasised in persons with a higher degree of alcohol addiction [21].

The study of psychosocial impulsiveness predictors in alcohol addicts showed that a lack of education, social support, hard economic situation, experience of sexual or physical abuse before the age of 18 were potential impulsiveness correlates, whereby most of the factors were related to cognitive impulsiveness. In case of behaviour impulsiveness in alcohol addicts, it was shown that the genetic influence was much more expressive, while the psychosocial influence and the influence of demographic factors were much more expressed in cognitive impulsiveness [22].

Caspi et al. showed that there was not only an increased level of impulsiveness in alcohol addicts, but also that impulsiveness was present as a personality trait before the development of a complete alcohol addiction [23]. Dom et al. studied the correlation between impulsiveness and age at drinking onset. They established that in persons who began drinking alcohol at younger ages impulsiveness as a personality trait was more expressed compared to persons who began drinking alcohol at older ages. It can be concluded that the age at drinking onset is inversely proportional the impulsiveness level [24].

Impulsiveness is also an important risk factor for the development of suicidal behaviour [25]. Studies showed that the lifelong risk of attempting suicide in alcohol addicts was approximately $7 \%$ and that approximately 70 $\%$ of these attempts were impulsive $[26,27]$.
The above-mentioned studies and past clinical experience showed that impulsiveness, in particular the cognitive component, played an important role both in the clinical course of alcohol addiction affecting recovery and rehabilitation of alcoholics, but also as an important prognostic factor for the development of relapse of drinking.

\section{Impulsiveness in pathological gambling}

For a very long time, there have been disagreements about the earlier adapted classification of pathological gambling among experts since the International Classification of Diseases and the $4^{\text {th }}$ edition of the Diagnostic and Statistical Manual of Mental Disorders classified it into impulse control disorders, while at the same time a growing number of conducted surveys highlighted a more obvious similarity with psychoactive substance addictions. The very fact that gambling is classified among impulse control disorders indicates that impulsiveness has an important role in the clinical course and the need to determine the impulsiveness level during the initial evaluation of a pathological gambler with the aim to select adequate treatment interventions. A study conducted by the $\mathrm{Na}$ tional Health Institute and medical studies in France analysed around 40 studies aimed at analysing the correlation between gambling problems and impulsiveness. A large number of these studies showed that there was a significant impulsiveness level among pathological gamblers compared to the control group and that there was a positive correlation between both the impulsiveness level and the intensity of the very gambling addiction [28].

As the clinical experience was growing, the awareness that pathological gamblers were not a homogeneous population and that 
there were among them certain subgroups with their own specificities which could be important for an adequate treatment approach was growing as well. In creating the classification of pathological gamblers, impulsiveness, i.e., types and intensity of impulsiveness played an important role. McCormick thus described the hyperactive subtype of pathological gamblers as such who had a feeling of being chronically insufficiently stimulated and who were in constant search for a relief of the feeling of dissatisfaction and non-structuralism, i.e., boredom [29]. The same population of gamblers was described by Rosenthal and Lesieur as constant action seekers and as a population being hyperactive, impulsive and lacking capacities for enduring emotional tensions, hypomanic and enduring a constant intra-psychic tension. In this subgroup of pathological gamblers, special emphasis was put on the prevalence of boredom and the role gambling plays in coping with the chronical experience of a dissatisfying and non-structured everyday life whereby the gambling form was selected based on the above-mentioned so that most games in this subgroup were technically more complex, competitive and with higher stakes and possible payouts [30]. Lesieur analyzed, in his later studies, the pathological gamblers in hospital treatment by using questionnaires for evaluating, first of all, impulsiveness and then gambling intensity, sensation seeking, depression, anxiety and dissociation. Based on the conducted study, he identified three subtypes of pathological gamblers:

1) "Normal" pathological gamblers with rather few psychopathological symptoms, except gambling;

2) Moderately impulsive action seekers with a moderate impulsiveness and psychopathology level, earlier age of gambling ini- tiation and a higher level of narcissistic personality traits and a feeling of power in the context of gambling related to narcissism; and

3) Impulsive escape seekers with a significant impulsiveness level (in relation to other subtypes), a higher depression and anxiety level; gambling was interpreted as a means of escaping aversive affective states [31].

Furthermore, some theoretical gambling models, like the pathway model by Blaszczynski and Nower, gave an importance to impulsiveness and impulsive personality traits as predisposing factors for the development of gambling addiction. They define a special subtype of gambling addicts called antisocial impulsive type. A specific feature for this type of gamblers is that they engage into a large number of risky behaviours at an early age regardless of the gambling itself, including the abuse of psychoactive substances (in particular alcohol and polytoxicomania), suicidal and parasuicidal behaviour. They have inadequate interpersonal relations, positive family history for antisocial behaviour and alcohol-caused disorders. Gambling usually starts at an early age and its intensity escalates fast. The early involvement into criminal behaviour related to gambling is also present. There is a low motivation for treatment, low cooperation and weak response to any kind of treatment intervention. The impact of impulsiveness in this type of pathological gamblers is an interactive process aggravated under both pressure and influence of negative emotions [32]. Blaszczynski found the support for introducing the subtype of antisocial impulsive gamblers in earlier studies he had done with Steel when they conducted a study on the correlation between impulsiveness, antisocial characteristics and gambling 
on a sample of 115 gamblers. That study showed an important correlation between the level of psychological distress with impulsiveness and antisocial personality traits. It showed that pathological gamblers with comorbid psychoactive substance abuse had a more expressed impulsiveness and more expressed affective disorders in relation to persons with only psychoactive substances abuse [33]. Similar to this group was the so-called third gambler cluster described by GonzalezIbanez et al. who stated that these were persons with a large number of problems caused by gambling, expressed impulsiveness, disinhibition and low tolerance on boredom in relation to other gamblers [34]. The role of abuse of psychoactive substances and impulsiveness in the development of pathologic gamblers was also confirmed by Petry in his study who described that there was a significant and positive correlation between these factors [35].

The impulsiveness of gamblers from an aspect of biological predisposition was studied by Rugle and Melamed by conducting neuropsychological measurements of attention disorder in 33 pathological male gamblers and in the control group. They concluded that there is a certain evidence related to attention disorder, which could reflect impulsive personality traits at an early age and could have predictive values for the development of pathological gambling. This biological vulnerability could weaken behavioural control not only regarding gambling, but also in other areas of life implying that impulsiveness could have existed before gambling, that it did not depend on gambling and that it was a good predictive factor for determining the intensity of pathological gambling, at least in certain subgroups of gamblers [36].
Considering the expressivity, i.e., presentation of certain impulsiveness components in pathological gamblers, the study conducted by Whiteside et al. is particularly interesting. These researchers initially structured psychometric instruments for the impulsiveness assessment - the so-called UPPS Impulsive Behaviour Scale by aaplying the previously used surveys for impulsiveness assessment and the five-factor theory model of personality. This instrument defines four components of impulsiveness:

1) Urgency as a tendency of developing strong impulses by the action of negative emotions;

2) Premeditation which is described as thinking about some act before doing it;

3) Persistence (i.e., lack of persistence) as an ability to end a certain task under the action of distractive stimuli; and

4) Sensation seeking which is described as indulging into activities where the participation is accompanied by a high level of sensation and openness to new experience, which may or may not be dangerous.

The validation of the questionnaire was conducted on a population characterised by a high level of impulsiveness such as borderline personality disorders, pathological gamblers and drug addicts parallel with the control group analysis. The simultaneous regression analysis showed that urgency was the most consistent predictor of all four components and the multiple regression analysis showed that urgency was an important predictor of pathological gambling $[37,38]$. Cyders and Smith analysed the role of impulsiveness in the development of pathological gambling and bulimia nervosa and they put an emphasis on urgency in their studies. They distinguished two types of urgency - positive and 
negative - depending whether the person engaging into a specific activity experienced pleasant or unpleasant emotions. The study they conducted on a population of students showed that positive urgency, lack of planning and sensation seeking were in correlation with gambling behaviour. However, only positive urgency was described as a predictive factor for intensifying gambling activities. A significant limit of the study was that the subjects were mostly women, while pathologic gambling was more often with men. The prevalence of pathological gambling could also not be determined as the structure of the study did not enable this and it could not be determined whether the study results had been influenced been by the intensity of the very disorder [39,40]. Michalczuk et al. concluded in their comparative study that the biggest difference between pathological gamblers and a healthy control group was in the positive and the negative urgency. The significant difference between the afore-mentioned two groups was in the lack of planning and lack of persistence while the part related to sensation seeking did not differ [41].

The occurrence of impulsiveness in pathological gamblers, i.e., gamble addicts was also studied from the aspect of its impact on the treatment results in addicts involved in treatment protocol. Several conducted studies showed that among pathological gamblers involved in a treatment protocol, impulsiveness was a significant predictive factor of both relapse occurrence and failure of treatment intervention $[42,43]$. The influence of the categorization of gamblers according to the pathway model on the treatment results was studied by Ledgerwood and Petry. The subjects were divided in the study into the following groups:
1) Subjects with low depression and anxiety level, who had a less expressed intensity of illness and less psychosocial problems caused by gambling such as behaviourally conditioned gamblers;

2) Subjects with a high anxiety and depression level, but with a low impulsiveness level (such as emotionally vulnerable gamblers), with a higher level of registered psychopathology than behaviourally conditioned gamblers, positive family history of mental disorders, but with smaller social consequences of gambling in relation to subjects with a high impulsiveness level; and

3) Subjects with a high impulsiveness, anxiety and depression level, early beginning of addiction development, positive family history of addiction or mental disorders, elements of antisocial personality disorders, expressed social consequences of gambling (such as antisocial impulsive gamblers).

In accordance with the pathway model, the authors assumed that the emotionally vulnerable gamblers would have a good treatment response to individual cognitive-behavioural treatment, but that their recovery would be slower compared to the behaviourally conditioned gamblers, while they assumed that the antisocial impulsive gamblers would show resistance to the applied treatment intervention. The study results showed that there were no differences in the treatment response between the three subgroups of gamblers they studied, i.e., that all three groups recovered with more or less the same dynamic [44-45].

Most of the conducted studies on the correlation between impulsiveness and pathologic gambling showed that during the initial diagnostic processing of each gambler addict, the level of presentation of impulsiveness in the clinical features should be taken 
into account since a large number of studies [46] showed that impulsiveness could play a significant role in diagnosis, prognosis and treatment, when working with these groups of patients.

\section{References}

1. Moeller FG, Barratt ES, Dougherty DM, Schmitz JM, Swann AC. Psychiatric aspects of impulsivity. Am J Psychiatry. 2001;158:1783-1793.

2. Arce E, Santisteban C. Impulsivity: a review. Psicothema. 2006;18:213-220.

3. Whiteside SP, Lynam DR. Understanding the role of impulsivity and externalizing psychopathology in alcohol abuse: Application of the UPPS impulsive behavior scale. Experimental and Clinical Psychopharmacology. 2003;11:210-17.

4. Patton JH, Stanford MS, Barratt ES. Factor structure of the Barratt impulsiveness scale. Journal of Clinical Psychology. 1995;51:768-774.

5. Butorac K. Neka obilježja osobnosti kao prediktivni čimbenici zlouporabe i ovisnosti o drogama i alkoholu. Kriminologija i socijalna integracija. 2010;18:79-98.

6. Swann AC, Bjork JM, Moeller FG, Dougherty DM. Two models of impulsivity: Relationship to personality traits and psychopathology. Biological Psychiatry. 2002;51:988-994

7. von Knorring L, Oreland L, von Knorring AL. Personality traits and platelet MAO activity in alcohol and drug abusing teenage boys. Acta Psychiatr Scand. 1987; 75:307-314.

8. Sher KJ, Trull TJ. Personality and disinhibitory psychopathology: alcoholism and antisocial personality disorder. J Abnorm Psychol. 1994;103:92-102

9. World Health Organisation. International classification of diseases - 10 (ICD-10). Geneva: WHO; 1990.

10. Američka psihijatrijska udruga. Dijagnostički i statistički priručnik za duševne poremećaje. Peto izdanje. Zagreb, Naklada Slap, 2014.

11. Tarter RE, Kirisci L, Feske U, Vanyukov M. Modeling the pathways linking childhood hyperactiv-

\section{Acknowledgements}

None

\section{Conflict of interest}

None to declare

ity and substance use disorder in young adulthood. Psychol Addict Behav. 2007;21:266-27.

12. Jentsch JD, Taylor JR. Impaired inhibition of conditioned responses produced by subchronic administration of phencyclidine to rats. Neuropsychopharmacology. 1999;24:66-74.

13. Ainslie, G. Specious reward: A behavioural theory of impulsiveness and impulse control. Psychological Bulletin. 1975;82:463-496

14. Dawe S, Loxton NJ. The role of impulsivity in the development of substance use and eating disorders. Neuroscience and Biobehavioural Reviews. 2004;28:343-351.

15. Babor TF, Hofmann M, Delboca FK,et al. Types of alcoholics: I. Evidence for an empirically derived typology based on indicators of vulnerability and severity. Arch. Gen. Psychiatry 1992;49:559608.

16. Cloninger CR, Sigvardsson S, Bohman M. Childhood personality predicts alcohol abuse in young adults. Alcoholism: Clinical and Experimental Research. 1988;12:494-505.

17. de Wit H. Impulsivity as a determinant and consequence of drug use: a review of underlying processes.Addict Biol. 2009;14:22-31.

18. Swann AC. The strong relationship between bipolar and substance-use disorder. Ann N Y Acad Sci. 2010;1187:276-293.

19. Poling J, Kosten TR, Sofuoglu M. Treatment Outcome Predictors for Cocaine Dependence. American Journal of Drug \& Alcohol Abuse. 2007;33:191-206.

20. Jakubczyk A, Klimkiewicz A, TopolewskaWochowska A, Serafin P, Sadowska-Mazuryk J, Pupek-Pyzioł J, Brower KJ, Wojnar M. Relationships of impulsiveness and depressive symp- 
toms in alcohol dependence. J Affect Disord. 2012;136:841-847.

21. Joos L, Goudriaan AE, Schmaal L, De Witte NA, Van den Brink W, Sabbe BG, Dom G. The relationship between impulsivity and craving in alcohol dependent patients. Psychopharmacology (Berl). 2013;226:273-83.

22. Jakubczyk A, Klimkiewicz A, TopolewskaWochowska A, Serafin P, Sadowska-Mazuryk J, Pupek-Pyzioł J, Brower KJ, Wojnar M. Psychosocial predictors of impulsivity in alcohol-dependent patients. J Nerv Ment Dis. 2013;201(1):43-47.

23. Caspi A, Begg D, Dickson N, Harrington H, Langley J, Moffi TE, Silva PA. Personality differences predict health-risk behaviors in young adulthood: Evidence from a longitudinal study. Journal of Personality and Social Psychology. 1997;73:10521063.

24. Dom G, Hulstijn W, Sabbe. Differences in impulsivity and sensation seeking between earlyand late-onset alcoholics. Addictive Behaviors. 2006;31:298-308.

25. BacaGarcia E, Diaz-Sastre C, Garcia Resa E, Blasco $\mathrm{H}$, Braquehais Conesa D, Oquendo MA, Saiz-Ruiz J, de Leon J. Suicide attempts and impulsivity. Eur Arch Psychiatry Clin Neurosci. 2005;255:152-156.

26. Wojnar M, Czyż E, Strobbe S, Klimkiewicz A, Jakubczyk A, Glass J, Brower KJ. Impulsive and non-impulsive suicide attempts in patients treated for alcohol dependence. J Affect Disord. 2008;115:131-139.

27. Kirisci L, Tarter R, Mezzich A, Vanyukov M. Developmental trajectory classes in substance use disorder etiology. Psychol Addic Behav. 2007;21:287296.

28. Collective, Expertise. Jeux de hasard et d'argent. Contextes et addictions. 2008, Paris: Les éditions INSERM.

29. McCormick RA. The importance of coping skill enhacement in the treatment of pathological gambler. Journal of Gambling Studies. 1994;10:77-86.

30. Rosenthal R, Lesieur H. Self-reported withdrawal symptoms and pathological gambling. American Journal of Addictions. 1992;1:150-154.

31. Lesieur HR. Cluster analysis of types of inpatient pathological gamblers. Disertacion Abstracts International. 2001;62(4-B):2065.
32. Blaszczynski A, Nower L. A Pathways Model of Problem and Pathological Gambling. Addiction, 2002;97: 487-499.

33. Steel Z, Blaszczynski A. The factorial structure of pathological gambling. Journal of Gambling Studies. 1996;12:3-20.

34. Gonzalez Ibanez A, Jimenez S, Aymami MN. Evaluacion y tratamiento cognitivo-conductal de jugadores patologicos de maguinas recreativas con premio. Anuario de Psicologia. 1999;30:111-25.

35. Petry NM. Substance abuse, pathological gambling and impulsiveness. Drug and Alcohol dependence. 2001;63:29-38

36. Rugle L, Melamed L. Neuropsychological assesment of attention problems in pathological gamblers. Journal of Nervous and Mental Disease. 1993;181:112.

37. Whiteside SP, Lynam DR. The five factor model and impulsivity: Using a structural model of personality to understand impulsivity. Personality and Individual Differences. 2001;30:669-89.

38. Whiteside SP, LynamDR, Miller JD, Reynolds SK. Validation of the UPPS impulsive behaviour scale: A four model of impulsivity. Europian Journal of Personality. 2005;19:559-74.

39. Cyders MA, Smith GT. Clarifying the role of personality dispositions in risk for increased gambling behavior. Personality and Individual Differences. 2008a;45:503-508.

40. Cyders MA, Smith GT. Emotion-based dispositions to rash action: positive and negative urgency. Psychological Bulletin. 2008b;134:807-28.

41. Michalczuk R, Bowden-Jones H, Verdejo-Garcia A, Clark L. Impulsivity and cognitive distortions in pathological gamblers attending the UK National Problem Gambling Clinic: A preliminary report. Psychological medicine. 2011;41:2625-35.

42. Leblond J, Ladouceur R, Blaszczynski A. Which pathological gamblers will complete treatment. $\mathrm{Br}$ J Clin Psychol. 2003;42:205-209.

43. Maccalum F, Blaszczynski A, Ladouceur R, et al. Functional and disfunctional impulsivity in pathological gambling. Pers Individ Dif. 2007;43:182938.

44. Ledgerwood DM, Petry NM. Subtyping pathological gamblers based on impulsivity, depression and anxiety. Psychol Addict Behav. 2010;24:680-88. 
45. Puharić Z, Kudumija Sljepčević M, Badrov T, Petričević N. Gambling among Teenagers in Bjelovar-Bilogora country (Croatia). Alcohol Psychiatry Res 2016;52:5-16.
46. Malčić T, Kudumija Sljepčević M. Differences in the knowledge and attitudes between students of tehnical and nursing studies towards alcohol and alcoholism, Alcohol Psychiatry Res 2015:51:15-50.

\section{Impulzivnost kod ovisnosti o alkoholu i patološkog kockanja}

Sažetak: Veliki broj provedenih istraživanja, jednako kao i svakodnevno kliničko iskustvo pokazali su važnu ulogu impulzivnosti u kliničkom tijeku te u terapijskom odgovoru i kod ovisnosti o psihoaktivnim tvarima, poput ovisnika o alkoholu, i kod bihevioralnih ovisnosti, poput ovisnosti o kockanju. U svakodnevnoj praksi, impulzivnost, kao crta ličnosti, promatra se ili u kontekstu determinirajućeg odnosno uzročnog čimbenika u razvoju ovisnosti, ili kao posljedica razvijene ovisnosti. Određeni tipovi impulzivnosti zastupljeni su češće kod određenih tipova ovisnika, a njihovim detektiranjem omogućava se preciznije dijagnosticiranje i subklasifikacija te adekvatnija prilagodba terapijskog protokola. Prema provedenim istraživanjima, pojava impulzivnosti značajno utječe na pojavu relapsa kod liječenih ovisnika, te dobrim djelom određuje opseg terapijskog odgovora na provedene terapijske postupke. Cilj je ovog preglednog članka ukazati na specifičnosti pojavnosti određenih elemenata impulzivnosti kod ovisnika o psihoaktivnim tvarima, poput ovisnika o alkoholu, i kod bihevioralnih ovisnika, poput ovisnika o kockanju, te dodatno naglasiti njihovu kliničku, dijagnostičku, terapijsku i prognostičku vrijednost.

Ključne riječi: patološko kockanje, alkoholizam, impulzivno ponašanje. 